Session 2542

\title{
Making the Link between Engineering Management and Undergraduate Research
}

\author{
David F. Radcliffe and Josh Humphries \\ Catalyst Centre for Society and Technology \\ The University of Queensland \\ Australia
}

\begin{abstract}
This paper describes and analyses an innovative engineering management course that applies a project management framework in the context of a feasibility study for a prospective research project. The aim is to have students learn aspects of management that will be relevant from the outset of their professional career while simultaneously having immediate value in helping them to manage a research project and capstone design project in their senior year. An integral part of this innovation was the development of a web-based project management tool. While the main objectives of the new course design were achieved, a number of important lessons were learned that would guide the further development and continuous improvement of this course. The most critical of these is the need to achieve the optimum balance in the mind of the students between doing the project and critically analyzing the processes used to accomplish the work.
\end{abstract}

\section{Introduction}

In most industries, engineering is increasingly managed through projects. As a new employee, young graduates are expected to operate effectively as a member of a project team and even to manage a small team. However, "traditional" baccalaureate engineering management courses focus on general management principles and practices more relevant to larger organizations than to project teams and are concerned with issues more applicable to engineers in mid-career. It is not surprising therefore that students often struggle to see the relevance of much of this material. This question of relevance for students is compounded by the quite different epistemology of engineering management courses and the reaction to it by students conditioned by mathematically based engineering science courses.

Simultaneously there are pressures to provide more experience in research for baccalaureate students [1]. This is in addition to team-based experiences gained through capstone design projects. By recognizing the immediate need that students have to manage their capstone design and research projects successfully, engineering management can be made experiential and more meaningful for students. 
In many Australian engineering schools, senior students undertake a year-long research thesis. This project typically involves experimentation, simulation or an industry-based investigation. It is undertaken individually and is usually worth a quarter of the credit for the year. In addition, senior students typically undertake a team based capstone design project, also worth one quarter of the credit for the year. Unlike their peers in the humanities and the social sciences, engineering students do not normally have a course on "research methods". Rather, preparation for undertaking a research thesis is assumed to accumulate from their exposure to research methods in laboratory classes (experimental and computer based) throughout their degree program. This can be considered a shortcoming as we become more intentional about developing the research capabilities of engineering graduates.

This paper presents an innovative engineering management course based on the principles of project management and incorporating an introduction to planning a research project. While there have been numerous attempts to integrate capstone design projects and engineering management [2] and more particularly especially project management [3-4], the opportunity afforded by capstone research projects for learning about engineering management is less well developed.

\section{Course Concept}

A new style of course in Engineering Management and Communication, MECH3600, was developed and implemented during 2003. It is a compulsory course for all juniors in Mechanical Engineering at the University of Queensland. The objective was to have the students experience engineering management in the form of project management in a team and to reflect upon the lessons they learn by the experience. This initiative grew from the need to create a learning experience for students than was more engaging than that provided by a "traditional" lecture based engineering management course with its attendant problems of student motivation.

Our innovation was to have the students undertake a feasibility study that defines and plans for a prospective baccalaureate research project. By this process, the students not only experience most aspects of project management but they also develop skills to prepare them for undertaking a research project. Thus it achieves two key program objectives. An integral part of this innovation was the introduction of a web-based project management tool, Project Web. The use of purpose designed web-based team collaboration tools in student design teams is well established [5]. Proprietary e-learning environments have been applied support project management in student teams [6]. Uniquely, Project Web facilitates teamwork and provides the students with data that they can use to analyze how well they have managed a project.

The new course addresses the need to incorporate more explicit instruction on conducting research in a creative way by placing the focus on using engineering management techniques to guide and foster research and critical analysis skills to (i) identify and formulate engineering problems in a research or design context and (ii) to plan and control a prospective project. The framework used is based on the nine areas of knowledge of project management identified by the Project Management Institute in the PMBOK [7], i.e. integration; scope management; time management; cost management; quality management; human resource management; communications management; risk (and opportunity) management and procurement. Importantly, this project management framework provides an introduction to engineering management more generally. 
One of the subtle concepts underpinning the course design is the fact that the basic elements in a project are replicated at all stages of the life cycle of the project, albeit at increasing levels of detail. The nine areas of knowledge of project management apply to every stage and each level. A typical project has four broad stages, (i) conception (or initiate, define), (ii) design (or plan), (iii) implement (or execute) and (iv) handover (or close). In turn, each of these stages can be subdivided into the same four stages. For instance, the conception phase involves definition (conception), it involves planning or design, it involves implementation and there is a handover to the planning phase of the project as a whole. Thus all project stages and hence all aspects of project management, can be experienced without completing the whole project.

Using this idea, the typical senior research thesis is considered to be composed of two sequential studies; a feasibility study and the full study. Each involves definition, planning, execution and handover. During the second semester of one year, juniors in MECH3600 work in teams to undertake a feasibility study into a prospective research project and they deliver a project plan. In the subsequent year, one or more students (not necessarily from the group who conducted the relevant feasibility study) undertake the thesis, commencing with the plan provided from MECH3600. This is illustrated in Figure 1.

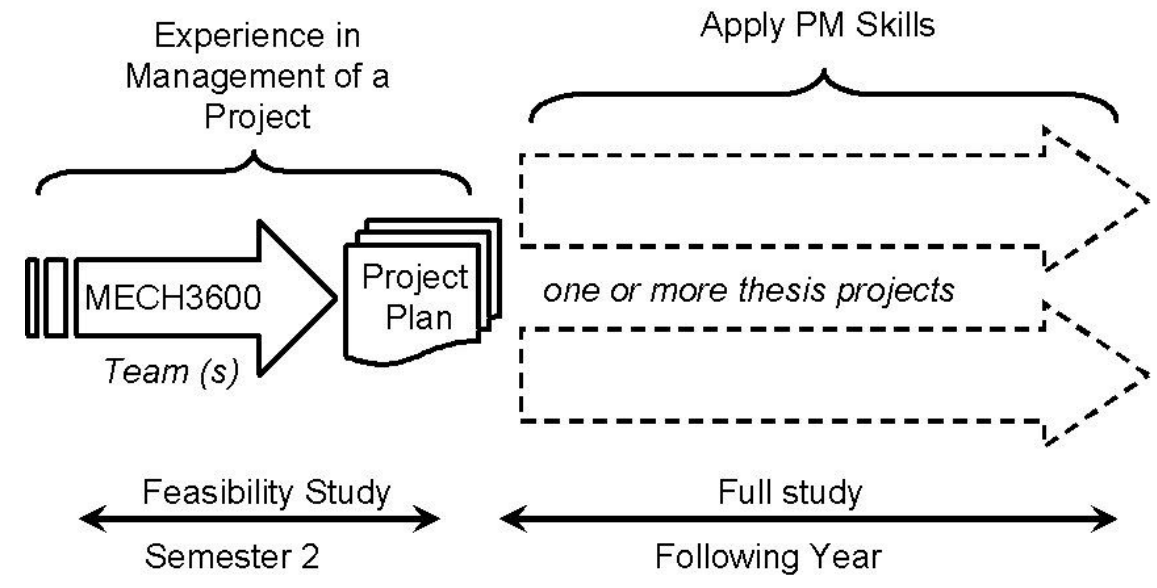

Figure 1- Relationship between Feasibility Study and Thesis

Thus the students experience the four stages of a project and consequently all nines elements of project management by conducting the feasibility study of the proposed thesis topic.

\section{Course Objectives}

The course outline informs the students that the aim of the course is to "prepare you as a graduate engineer to manage engineering work in an effective, efficient and professional manner taking into account all stakeholders. The knowledge and skills gained should assist you to identify, formulate, plan and undertake research and development projects, engineering design projects or engineering investigations, either as a member of a team or as an individual investigator. Thus it provides a foundation for undertaking your final year research thesis and a capstone design project."

The learning objectives are as follows; 
Table 1 - Learning Objectives

\begin{tabular}{|c|c|}
\hline Objective & Description \\
\hline \multirow{3}{*}{$\begin{array}{l}\text { Critically analyze } \\
\text { the context of a } \\
\text { prospective project }\end{array}$} & $\begin{array}{l}\text { Identify and critically review the "prior art" and other relevant } \\
\text { information in relation to a proposed engineering project. }\end{array}$ \\
\hline & $\begin{array}{l}\text { Identify all the stakeholders and their relationship to the proposed } \\
\text { project including legal, regulatory or contractual requirements. }\end{array}$ \\
\hline & $\begin{array}{l}\text { Assess the possible impacts of the project on each of the } \\
\text { stakeholders and define the relevant measures of effectiveness, } \\
\text { success factors and Key Performance Indicators (KPI) for the project } \\
\text { for all stakeholders. }\end{array}$ \\
\hline Scope a project & $\begin{array}{l}\text { Clarify and define a realistic engineering project in precise and } \\
\text { unambiguous terms commencing from an initial need or limited brief } \\
\text { and based on an understanding of the project life cycle. Conduct a } \\
\text { project feasibility study as part of this process. }\end{array}$ \\
\hline $\begin{array}{l}\text { Select appropriate } \\
\text { methods }\end{array}$ & $\begin{array}{l}\text { Identify and select the most appropriate approach to tackling the } \\
\text { project and explain your rationale. }\end{array}$ \\
\hline $\begin{array}{l}\text { Estimate project } \\
\text { resources }\end{array}$ & $\begin{array}{l}\text { Taking into account the context, scope, and methods selected, } \\
\text { estimate the types, amounts and sequence of resources required to } \\
\text { accomplish the project objectives within a given time, budget and } \\
\text { quality framework. }\end{array}$ \\
\hline Manage project risk & $\begin{array}{l}\text { Identify all possible sources of risk for the project across its life cycle } \\
\text { and develop plans to manage these effectively throughout the } \\
\text { project. This includes HSE risks. Implement risk management within } \\
\text { a feasibility study. }\end{array}$ \\
\hline $\begin{array}{l}\text { Plan, monitor and } \\
\text { control a project }\end{array}$ & $\begin{array}{l}\text { Develop project plans and establish measure to monitor and control } \\
\text { performance and progress. Define, plan and implement a quality } \\
\text { process to maximize the probability of success for the project. } \\
\text { Estimate earned value of project to date. }\end{array}$ \\
\hline & $\begin{array}{l}\text { Maintain a professional workbook and manage shared documents } \\
\text { and other information in a professional manner. }\end{array}$ \\
\hline $\begin{array}{l}\text { Document } \\
\text { thoroughly }\end{array}$ & $\begin{array}{l}\text { Prepare reports that communicate and document progress and final } \\
\text { results and recommendations from a project in a manner that is } \\
\text { clear, concise, complete, consistent, coherent, and convincing } \\
\text { (based on evidence). }\end{array}$ \\
\hline Present effectively & $\begin{array}{l}\text { Communicate relevant information orally in an effective manner to } \\
\text { influence a variety of stakeholders associated with a project. This } \\
\text { includes formal project reviews or presentations and impromptu } \\
\text { discussions and communications during the course of a project. }\end{array}$ \\
\hline
\end{tabular}

\section{Course Operation}

There are 100 120 students in the class. The students work in teams of $5 \sim 6$ to conduct a feasibility study for one project. This feasibility study explores the literature and related prior art to formulate the problem. It involves some consultation with faculty members as the client and the presentation of a series of reports, two interim and one final, at approximately 4 weekly intervals, as indicated in Figure 2. Each is associated with an oral presentation with the same focus. 


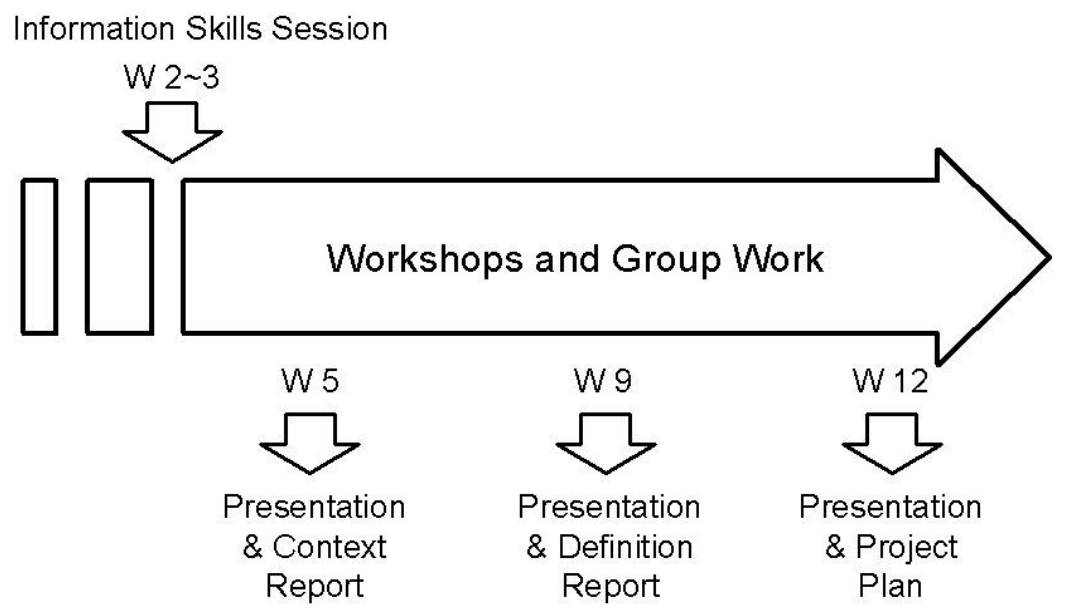

Figure 2 - Learning Activities and Deliverables

The first report, the Context Report, is intended to provide a comprehensive analysis of the context of the proposed project including all the stakeholders, their relationship to the project, a critical summary of the prior art that helps to shape the project or can be used in the project, list the constraints and potential risks, summarize the objectives of the project and identifies Key Performance Indicators (KPIs) for the project.

To assist with establishing the project through a literature search, staff from the University Library provide hands-on workshops plus ongoing support for the students to help them to develop their skills in locating and assessing information from a variety of sources including journals and databases. This is one of a series of such workshops held across the four years of the program, each linked to a particular course.

The Definition Report is intended to define what is to be done, why, how and what resources it will require. This report is meant to scope the project and include an updated set of objectives and KPIs, discuss the duration, estimate the budget, outline the approach to be taken and methods to be used and why in relation to the prior art, list the expected deliverables and include a risk assessment and a value management exercise. Thus this second report builds directly on the first.

The final report provides a detailed Thesis Project Plan to achieve the scope of work in the proposed thesis. It includes a project schedule, a quality management plan, a risk management plan, a communications plan, a procurement plan, a performance management plan and a document management plan. Importantly it also contains a critical analysis of the operation, monitoring and control of the team project across the semester.

The Context Report is worth 10\%, the Definition Report is worth $20 \%$ and the Project Plan (final report) is worth $40 \%$. The relative weightings of these reports reflect the progressive nature of the expected learning in this course. Reports are graded and returned within a week so that the students can learn and use the feedback to improve subsequent reports. 


\section{Course Scope}

The course covers both the nature of engineering projects and the processes of project management. While the context is a feasibility study of a prospective research project, material of a more general nature is covered in the course. For example, there is a workshop on financial accounting. The required text [8] and the recommended reading were chosen to reflect this scope [9-10].

Table 2 - Scope of Course

\begin{tabular}{|l|l|}
\hline Topic & Description \\
\hline Engineering Projects and & $\begin{array}{l}\text { Engineering projects - types (R\&D, feasibility, EPC, operations), } \\
\text { project life cycles, success factors, KPIs. Contractual basis of } \\
\text { projects - traditional and new types. Project selection - time } \\
\text { value of money, evaluation criteria, triple-bottom line. } \\
\text { Engineering ethics and social responsibility. Engineering } \\
\text { methods: design processes and methods and engineering } \\
\text { research methods review. }\end{array}$ \\
\hline Project Integration & $\begin{array}{l}\text { Management Project Planning - project management plans; } \\
\text { Project Execution - performance management; Overall Change } \\
\text { Control - configuration management. }\end{array}$ \\
\hline Project Scope & $\begin{array}{l}\text { Scope management - planning, definition, verification and } \\
\text { change control. Value management. }\end{array}$ \\
\hline $\begin{array}{l}\text { Project Time } \\
\text { Management }\end{array}$ & $\begin{array}{l}\text { Activity definition. Sequencing. Activity duration estimating. } \\
\text { Schedule development and control. }\end{array}$ \\
\hline $\begin{array}{l}\text { Project Cost } \\
\text { Management }\end{array}$ & $\begin{array}{l}\text { Resource planning. Cost estimating. Budgeting. Financial } \\
\text { accounting. Cost control. }\end{array}$ \\
\hline $\begin{array}{l}\text { Project Quality } \\
\text { Management }\end{array}$ & $\begin{array}{l}\text { ISO 9000. Quality processes and planning. Quality assurance. } \\
\text { Quality control. Documents and systems. }\end{array}$ \\
\hline $\begin{array}{l}\text { Project Human Resource } \\
\text { Management }\end{array}$ & $\begin{array}{l}\text { Organizational planning. Team development - phases. } \\
\text { Leadership. Professional development. }\end{array}$ \\
\hline $\begin{array}{l}\text { Project Communications } \\
\text { Management }\end{array}$ & $\begin{array}{l}\text { Communication plan. Knowledge management. Performance } \\
\text { reporting. Reviews and other oral presentations. Report } \\
\text { preparation. }\end{array}$ \\
\hline $\begin{array}{l}\text { Project Risk } \\
\text { Management }\end{array}$ & $\begin{array}{l}\text { Technical, time, and schedule risks. Health, safety \& } \\
\text { environmental (HSE), and societal risks. Risk identification. Risk } \\
\text { quantification. Risk response development. Monitoring and } \\
\text { control. Contemporary issues in risk management in } \\
\text { engineering. }\end{array}$ \\
\hline Project Procurement & $\begin{array}{l}\text { Management Procurement planning. Contract administration. It } \\
\text { is assumed that you have completed at least five semesters of } \\
\text { an engineering program. This should include one or more } \\
\text { courses in each of the engineering sciences underpinning your } \\
\text { discipline and one or more design courses including some } \\
\text { project work (e.g. ENGG1000). }\end{array}$ \\
\hline
\end{tabular}




\section{Learning Activities}

Most of the learning objectives are about the process of how engineering is done in practice. Accordingly the learning activities were designed to be a series of structured experiences to develop the process capabilities of the students. It was anticipated that the discipline required to stay committed, to maintain good documentation, to run effective meetings, to follow through and to deliver would be fostered.

In place of traditional lectures, the new design of the course envisaged weekly workshop sessions modeled on workshops used in professional practice for developing capability in individuals and teams. This objective was to make it experiential, with students learning by undertaking a project. Various project management concepts, methods and techniques would be introduced and then applied by the students in the context of their team project.

The structure of this course is expressly designed to prepare and empower students to undertake projects as "critical" participants and to learn and to improve from the lessons of the experience. The key to this was to develop their ability to reflect on project experiences and to draw lasting insights from this reflection. Through a professional development log, students had to engage in reflection-in-action as part of the process of being aware of their emerging professional attributes. Students were expected to learn to make judgments of consequence. The role of the instructors was as coach and mentor.

Each member of faculty was invited to submit a prospective thesis research topic in the form of a client brief. The purpose of this document was to provide students with a concise description of the potential project. The information requested included a short, descriptive title, background information to orientate the students to the area of research, a brief introduction to the field of research, and a paragraph to establish the context including the prior art. The project proposer also listed one or more issues or research question(s) with the focus on the question or issue to be addressed in the research and an indication if this topic may result in several thesis topics around a common theme and what these might be. Crucially they had to outline the expected outcomes of the thesis. To assist the students to get started on a literature review, the brief included some initial readings; 3 or 4 relevant pieces of background reading that can be accessed via the library or on the web. This is to kick start their literature review. The faculty were invited to include any other information that might help to orientate the students to their task of conducting the feasibility study. The project topics in 2003 were:-

1. Boundary Layer Transition (flight test)

2. Collaboratorium for Project Teams

3. CFD Infrastructure

4. Dynamics of Bells

5. Laminar defects in FR Beams

6. In-seam Coal Gasification

7. Design Management Metrics

8. Railways Noise

9. Virtual Construction Technology - 4D CAD

10. Integrated Systems Modelling Techniques 
To assist teams to meet regularly to plan, monitor and control progress in their project, a regular time was scheduled each week. This was not a formal class time, with the exception that several of these sessions are used early in the semester as workshops to accelerate start-up. Students could select their team. Each team was responsible for clarifying their task, managing their own project, assigning tasks and responsibilities, making presentations and producing project plans and reports. Each member of the team was expected to maintain a professional standard workbook. In addition, the team was expected to maintain a project folder or team web site that provides a summary of team decisions, status of the project, master schedules and the like.

\section{Project Web}

Project Web is a prototype collaborative tool for supporting student engineering project teams. It draws on the core ideas of commercial project management software but aims to deliver a much simpler, more accessible product that allows students to focus on and be actively guided through the fundamental concepts behind managing engineering projects.

The current version of Project Web contains the following tools:

- A multi level access area for describing the project

- Client briefing (uploaded by course coordinator)

- A multi level access area for maintaining and developing the project scope

- A multi level access area for maintaining and developing the project requirements

- Contact details of project members

- A discussion area

- A facility for setting meeting agendas and posting meeting minutes

- A file sharing library

- A project scheduling facility that monitors actual and projected time.

- An individual task allocation and monitoring facility.

The Project Web prototype was initially used in MECH3600 (Engineering Management and Communication) on a voluntary basis. There were nineteen student groups in the class. Groups actively engaged in the use of the available tools at various levels. Figure 3 shows the number of groups that actively used the various tools.

While use of Project Web was voluntary and not assessed, students were asked to reflect on their management practices and methods including their use (or otherwise) of project management as part of the course assessment. Analysis of this data indicates that the major obstacle to the use of Project Web was the barrier to entry, having to log in each time. In many cases students found it easier to email information. Students viewed the system primarily as a communication tool for completed work rather than a place to "do" work. 
Usage Levels of Online Tools

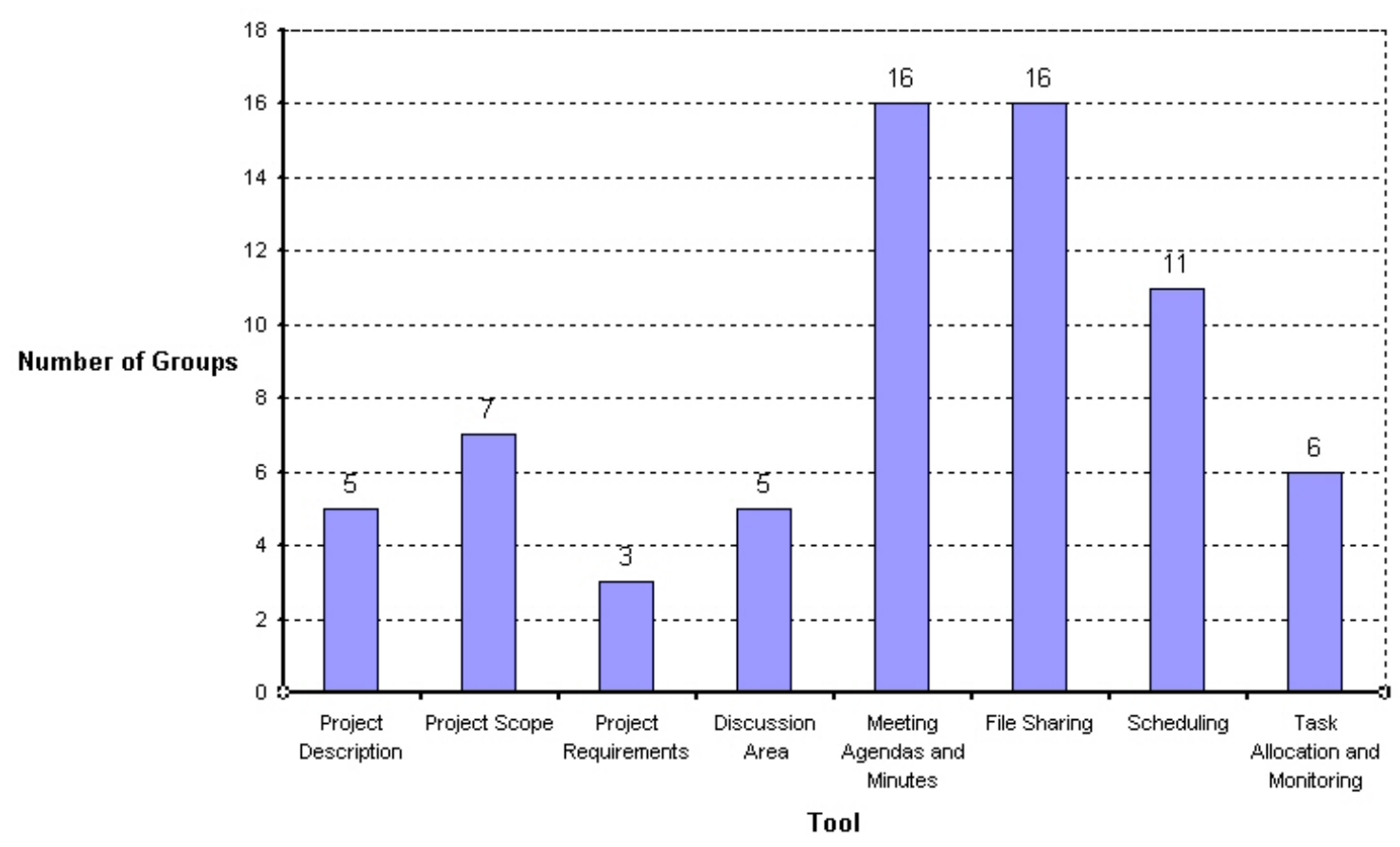

Figure 3 - Usage of Project Web Tools

The Project Description, Project Scope and Project Requirements tools were all multi level open text fields for publishing information. For each of the tools students could enter information that could be viewed publicly by the entire class or by the group. In hindsight it is not surprising that these tools were not utilized by the students to the extent anticipated. From a student's perspective, it is much easier to publish information on the project scope and requirements using more flexible tools like Word and Excel and use the file-sharing tool to distribute this information. Of the student groups who did use these tools, only one published information in the public and class areas, again highlighting that when designing such tools it is important to consider the differing motivations of students and industry professionals. Students are not interested in disseminating information any further than their immediate project group. It is intended that the next version of Project Web will offer a much more guided and value adding tool for managing the scope and requirements.

The use of the discussion area was also limited, this is primarily due to the barrier of entry, i.e. needing to remember to login and check the discussion board and the ease of using email as an alternative. Students did acknowledge that discussion boards do have an advantage in that it creates an easily accessible record of communications available to the whole group. One way of overcoming the barrier to entry is to use emails with imbedded hyperlinks to alert students of new postings.

The meeting minutes and agendas section was used by most groups but not always in the way that was intended when the system was designed. Most groups only used it for a proportion of their meetings and did not use the "Actions" function as they felt it was duplicated by the task allocation and monitoring tool. 
The scheduling tool was in essence an online Gantt chart that compared project progress with actual progress. Most students were familiar with this type of tool prior to the course and this is reflected in the high level of use. Of the groups that did not use this tool most used a similar tool from another package. One of the primary improvements for the next version of Project Web will be a tighter alignment between the scheduling tool, task allocation and monitoring tool and the actions component on the meeting minutes and agenda tool. In addition to reviewing the usage data and feedback from students Project Web will be further evaluated against a set of usability metrics and heuristics [11-13].

\section{Discussion}

Both students and faculty were consulted during the development of this course. The previous engineering management course, which the new course replaced, had a poor reputation amongst the students. The new concept was presented at an open forum during the formative stages of development of the course in order to seek comments and suggestions from students who had undertaken the traditional course in the preceding year. While student attendance at the forum was disappointing, some valuable suggestions arose which were incorporated into the final course design. The perennial problem in the evaluation and continuous improvement of courses is that students feel most strongly about a course when they are in the midst of it but are less vocal and concerned after the event. On the contrary, they often seem reluctant to see improvements made to problematic courses, preferring the students who follow them have to "suffer" as they did.

Several presentations were made at faculty meetings during the design phase of the course. This was especially critical as the new concept would involve the faculty providing projects and in the assessment of oral communication. While this process produced some useful ideas, the most important aspect of this was the need to gain "buy-in" by the faculty. Through the use of actual research projects provided by faculty, the new arrangements for the course had the potential to load faculty in a way that had not happened previously. Equally it provided them with an opportunity to get some pre-work done on forthcoming projects and to engage prospective thesis students.

It is clear from the comments of students during the course and their reflective analysis of the processes in their final reports, that they were sometimes confused about the scope of the feasibility study in relation to the thesis. They had questions as to whether they were doing the research or just planning it. In reality, it was expected that they would do some of the preliminary work such as a basic literature review that would otherwise have been in the thesis. This confusion meant that the project plans they produced were not always as useful for someone about to undertake the thesis, as might have been the case. This needs to be more clearly defined so that the expectations of the faculty who offer the projects are met as well as achieving the learning objectives for the students.

The PMBoK presents project management as a set of universal principles and practices, independent of the operational context. Nevertheless, there seems to be a tacit assumption of "construction" or at least physical activity as the context of a project embedded in the framing of the nine areas of project management, in the elements in each area and in some of the methods used. It was clear in the course that the projects that were based on physical experimentation (e.g. Boundary Layer Transition and Detecting defects in FC beams) resulted in project plans that more readily fitted the framework and which contained more technical information. The use of 
the nine universal principles presented in the PMBoK did have its drawbacks, particularly for the final report. The scale and nature of many of the projects meant that students had trouble distinguishing between time management, cost management and human resource management, as in most research projects the predominant resource required is a student's time.

Some students were unclear about the balance to be struck between doing of the work on the feasibility study and the analysis and reflection on this work. The reports, especially the final report, contained elements of assessment based on both the product and the process. The teams must engage in real work and achieve tangible project outcomes in order to have an experience of project management. This implies it should be included in the grading in order to give the students incentive. Nevertheless the primary objective of the course is to learn about the processes of management and this needs to be assessed meaningfully.

Upon reflection, the assessment criteria used to grade the student reports was too closely aligned one-to-one with the nine areas of project management in the PMBoK [7]. Conceptually this seemed the most intuitive and beneficial approach to reinforce the learning based on the areas. However it proved to be too restrictive due to the nature of some of the projects. In order to overcome this in the future it would be better to develop criteria that run across the PMBoK principles and allow the student more flexibility to tailor the make up of the final report to their particular project without concern about a possible loss of marks due to failure to address a particular element in the nine areas. One possible solution is to use criteria referenced grading that highlights the importance of particular areas. For example, to get an A overall you must get an A for assessment against criteria 1, 2 and 3 and an $\mathrm{A}$ in one of 4, 5 or 6.

In their final presentations and report the students were asked to make recommendations for improvements in the course. Many of these recommendations were predictable and offered by several groups, e.g. hold regular meetings with client, have a well defined scope and define it early, plan time carefully, implement effective management early, effective team work is essential throughout the whole project, appoint a leader and make a better use of Project Web. However there were also some more critical observations presented e.g. find a planning process that works for your team or the project should be reviewed at specific times, to ensure that the activities being carried out remain within the scope as defined in the project plan. Some recommendations were quite challenging. For instance, one group raised the suggestion that individuals and teams should set their goals in terms of the desired grade for the course from the outset - are we aiming for an $\mathrm{A}^{+}$or just a $\mathrm{C}$ ? While somewhat disheartening for the educator, this is a serious issue that deserves more attention and that is better raised than left unspoken.

\section{Conclusions}

An innovative means of integrating project management with the development of research capability in engineering students has been demonstrated. The approach has the potential to realize multiple benefits to all stakeholders. Students can gain relevant professional engineering skills plus immediate competencies for conducting senior projects. Faculty can benefit from work done on prospective research projects and having students better prepared to undertake a research thesis. However in order to realize this potential the subtleties of the concept must be carefully managed with students. Tailored assessment and value-adding management support tools are critical to achieving the balance between doing the project and critically analyzing the processes used accomplish it. 


\section{References}

[1] Gates, A.Q., Teller, P.T., Bernat, A., Delgado, N., and Della-Piana C.K (1999) Expanding participation n undergraduate research using affinity group model, J. Engg Educ., 88, Oct, 409-414.

[2] Farr, J.V., Lee, M.A., Metro, R.A. and Sutton, J.P. (2001) Using a systematic engineering design process to conduct undergraduate engineering management capstone projects, J. Engg Educ., 90, April, 193-197.

[3] Porter, J.R., Morgen, J.A. and Zoghi, B. (2002) Integrating project management into the capstone senior design course, Proceedings ASEE Conference and Exposition, Session 2648.

[4] Moor, S.S. and Drake, B.D. (2001) Addressing common problems in engineering design projects: a project management approach, J. Engg Educ., 90, July, 389-395.

[5]. Toye, G., Cutkosky, M., Leifer, L., Tenenbaum, M., and Glicksman, J. (1994) SHARE: A methodology and environment for collaborative product development, International Journal of Intelligent and Cooperative Information Systems, 3 (2), 129-153.

[6] Hailey, M.B., Jorgensen, J.E., Mescher, A.M. and Fridley, J.L (2001) Undergraduate collaborative capstone design project using the web, Proceedings ASEE Conference and Exposition, Session 3266,

[7] PMI (2002) A Guide to the Project Management Book of Knowledge (PMBoK), Project Management Institute, Upper Darby, PA.

[8] Burke, R (1999) Project Management: Planning and Control Techniques, Wiley, New York

[9] Beer, D. \& McMurrey, D. (1997), A Guide to Writing as an Engineer, Wiley, New York

[10] Samson, D. (ed) (1989) Management for Engineers, Longman, Cheshire, UK.

[11] Turns, J., M. Valeriano, and R.S. Adam. (2003) Websites for Engineering Educators: A Benchmark Study to Identify Best Practice. in Frontiers in Education Conference. Boulder, CO: IEEE.

[12] Farkas, D.K. and J.B. Farkas, (2000) Guidelines for Designing Web Navigation. Technical Communication, (Third Quarter): p. 341-358.

[13] Spyridakis, J.H., (2000) Guidelines for Authoring Comprehensible Web Pages and Evaluating Their Success. Technical Communication, Third Quarter): p. 359-382.

\section{Biographical Information}

DAVID RADCLIFFE has research interests in engineering systems design (theory and practice), engineering education and professional development, and knowledge management. This research is conducted as co-director of the Catalyst Research Centre for Society and Technology. It involves collaboration with partners from many engineering enterprises and other institutions and across discipline boundaries.

JOSH HUMPHRIES is a lecturer in the School of Engineering at the University of Queensland and an associate of the Catalyst Research Centre for Society and Technology. He has a Bachelor of Engineering (Mechanical) from UQ. Major research interests include; Engineering Education, Engineering Design, Technology and Society, Sustainability, Teaching and Learning and Virtual Groups. 